\title{
Analysis of Stock Pricing Factors
}

\author{
Jinyang Sun, Yicheng Hong* \\ College of Science, Yanbian University, Yanji, China \\ Email: *1210882991@qq.com
}

How to cite this paper: Sun, J.Y. and Hong, Y.C. (2021) Analysis of Stock Pricing Factors. Open Access Library Journal, 8: e8077. https://doi.org/10.4236/oalib.1108077

Received: October 13, 2021

Accepted: November 12, 2021

Published: November 15, 2021

Copyright $\odot 2021$ by author(s) and Open Access Library Inc.

This work is licensed under the Creative Commons Attribution International License (CC BY 4.0).

http://creativecommons.org/licenses/by/4.0/

\begin{abstract}
With the development of commodity economy and its productive forces, a product-stock is obtained. European securities market has formed a complete system, but Chinese stocks themselves have the characteristics of "controlling more with less" in trading. Because legal person shares and state-owned shares promise not to circulate when they are listed, each share is only tradable shares traded according to the stock price in the market, but the index is calculated according to the weighted total share capital. Therefore, the pricing of new shares listed in China still has some problems such as high underpricing and unreasonable listing price, which itself has non-market problems. Theoretically, company potential, development prospect, stock market status, number of issues, etc. may all become the influencing factors of IPO pricing. In order to prevent speculation and stabilize the stock market, it is necessary to analyze the pricing factors of new shares. Nowadays, stock pricing determines the equilibrium of stock market, and there are many factors that affect the pricing of new shares, which are divided into ontological factors and environmental factors in this study. Ontological factor It is the influencing factor of the issuance price when the stock issuer operates and manages internally. There are many kinds of environmental factors, such as the overall economic situation, policies, industries and so on. As an emerging market, the regulatory concepts and rules, investor maturity and intermediary service capabilities of China's capital market are constantly improving. The pricing mechanism of new shares is still being adjusted and improved. In view of this, this paper will analyze various factors that affect the pricing of new shares and use principal component analysis to reveal the relevant variables that affect the pricing level, sort out their importance, and put forward corresponding suggestions.
\end{abstract}

\section{Subject Areas}

Business Finance and Investment 


\section{Keywords}

Ipo Pricing, Listing, Factor Analysis

\section{Introduction}

With the continuous development of China's economy, as an emerging market, with the financial reform and development, although the financial market has been gradually improved, there are also some unstable factors in the development process. Under the strong fluctuation of the market, there will be an unreasonable premium. After the emergence of premium, there are corresponding policies, and there is an inquiry system. This is a way to price new shares. When new shares are issued, the price is determined by the issuer and the underwriters themselves. In 2004, the CSRC issued the Inquiry System according to the Pricing Principles of the Market to determine the price of new shares. When determining the price of a stock, according to the market demand of the issuer, the issuer and the investor will first determine the range of the issue prices through negotiation. Then set a price level acceptable to most investors, so as to determine the listing price of new shares [1]. On January 1, 2005, China implemented the Inquiry System of Initial Public Offering, which improved the legal environment of the securities market and protected the interests of investors. Nevertheless, there is no complete guarantee that there will be no premium or underpricing. Sometimes, supervision will be excessive or fail, and the protection mechanism for investors needs to be constantly improved. Therefore, this study will analyze the factors that affect the IPO pricing, and analyze the collected influencing factors by principal component analysis, and draw a significant correlation between variables and IPO price changes. There are many factors that have a certain influence on the pricing of new shares, but most of them are not very significant. Therefore, the main factors and environmental factors are selected for further analysis.

\section{The First Chapter Is the Pricing System of New Shares in China}

\subsection{Overview of Stock Pricing Theory}

\subsubsection{Stock Pricing Theory}

Stock pricing theory is regarded as a theory to determine the stock price and stock market under uncertain circumstances, which makes the financial market equilibrium. It focuses on the risk factors included in the necessary rate of return and their interrelationships. Because of its remarkable reality and widely used empirical test methods, it has become one of the active threads in financial economics in the past 50 years. Stock pricing theory has experienced a change from traditional pricing theory to modern pricing theory.

Modern pricing theory should be considered more for investors, so as to con- 
sider more comprehensively according to the real situation of investment. Investors generally form a portfolio (not one stock, but multiple stocks).

\subsubsection{Intrinsic Value Theory}

The research of intrinsic value theory began with the delivery of Benjamin Graham on Wall Street. As a securities analyst, his representative work is Securities Analysis, in which he puts forward that stock price fluctuation is based on intrinsic value of stocks. The future profitability of enterprises has a certain influence on intrinsic value [2]. After that, Gordon put forward the cash flow model of stock pricing based on the in-depth analysis of intrinsic value- "Gordon Model”. Gordon Model Has an important influence on stock analysis:

Dividend intimate model is the most important in intrinsic value theory, and its core principles are as follows:

$$
P_{0}=D_{0} /(1+r)+D_{2} /(1+r)^{2}+\cdots+D_{n} /(1+r)^{n}
$$

Here $P_{0}$ For the intrinsic value of stocks, $D_{1}, D_{2}, \cdots, D_{n}$ is the dividend, and $r$ is the discount rate.

From the formula of discount model, the following two simple formulas can be derived:

1) Stock Pricing Model under Fixed Dividend Growth Rate-Gordon Model

If the issuing company can keep the cash dividend of the stock on top of the basic dividend and increase at a fixed rate every year, the pricing model of the stock dividend is as follows:

$$
\begin{aligned}
& P_{0}=D(1+\mathrm{g}) /(1+r)+D(1+\mathrm{g})^{2} /(1+r)^{2}+\cdots+D(1+\mathrm{g})^{n} /(1+r)^{n} \\
& =D(1+g) /(r-g) \\
& \text { ( } g=\text { Fixed rate of dividend growth })
\end{aligned}
$$

2) Stock Pricing Model under Constant Dividend Condition

Assuming that the issuer of the stock keeps the amount of the stock unchanged and the investor holds the stock permanently, the pricing model of the stock is as follows:

$$
P_{0}=D /(1+r)+D(1+r)^{2}+\cdots+D /(1+r)^{n}=D / r
$$

\subsection{Changes in IPO Pricing System}

\subsubsection{Fixed Price System}

In the early days of the securities market, new shares were issued at a fixed price. Fixed issue price is more suitable for retail-dominated securities market, and fixed price leads to a low degree of marketization [3]. The formulation of this system is mainly calculated by price-earnings ratio, and the formula is:

Stock price $=$ earnings per share $\times$ reasonable price-earnings ratio.

Later, because the price-earnings ratio is more suitable for the trend of stocks in the secondary market, with the development of the securities market, this pricing system is easy to be manipulated, so that the IPO price of this pricing system is not suitable for the development of the securities market. 


\subsubsection{Development Stage of IPO Pricing System}

From 1999 to 2004, a variety of pricing systems appeared in China's securities market, as shown in Table 1.

From 1999 to 2004, the IPO pricing system has been changing constantly, which fully reflects the continuous efforts and innovations of China's financial market towards marketization. Nevertheless, the closing price of many new shares is still much higher than the opening price on the day of issuance, resulting in excess returns, which hinders the healthy development of China's financial market [4].

\subsection{Stock Issuance}

\subsubsection{Stock Discovery Summary}

Under normal circumstances, when a stock is issued, it will be publicly issued to the society and raise share capital. The mechanism of financial market has a great influence on the decision of price. With the change of the input value of the company and the change of the relationship between supply and demand in the market, the issue price of the stock will also change accordingly. If the price of a stock issued by the issuer is too much higher than the par value, it is called a premium issue. After consultation between the underwriting securities institution and the issuer, it will determine how much higher the par value can be and submit it to the securities regulatory authority under the State Council for approval. When the stock is issued, the mechanism of financial market determines the issue price of the stock, but at the same time it will be supervised and managed by the securities institution of the State Council.

\subsubsection{Issue Price of Shares}

In the stock issue price, premium issue or equivalent issue is allowed, but discount issue is not allowed, that is, it is sold at a price lower than the par value of the stock. In this case, the issue price will lead to the actual capital of the company being less than the due capital, which does not conform to the principle of

Table 1. Development of IPO pricing.

\begin{tabular}{|c|c|}
\hline Time (year) & Pricing system of new share issuance \\
\hline 1999 & $\begin{array}{l}\text { Strategic investors can participate in the pricing, and the issue price of } \\
\text { new shares is decided by the issuer and investors through negotiation. }\end{array}$ \\
\hline 2000 & $\begin{array}{l}\text { Pricing system in which primary market pricing and secondary market } \\
\text { investment are linked to gradually reduce the impact of price-earnings } \\
\text { ratio. }\end{array}$ \\
\hline 2001.05 & $\begin{array}{l}\text { The online bidding is determined for the first time, and the black-box } \\
\text { operation is effectively placed, which has a positive impact. }\end{array}$ \\
\hline 2001-present & $\begin{array}{l}\text { Reset the pricing system of } \mathrm{P} / \mathrm{E} \text { ratio, and determine the issuance interval } \\
\text { by preliminary inquiry. The IPO pricing breaks through the traditional } \\
\mathrm{P} / \mathrm{E} \text { ratio limit, specifically adopting the practice of "a certain total } \\
\text { amount, uncertain issuance volume, and the price only sets the base } \\
\text { price, not the upper limit". }\end{array}$ \\
\hline
\end{tabular}


capital enrichment of the company, and the company will have an imaginary number [5]. In fact, it shows that the company has debt behavior to creditors, and the company issues shares at a price lower than the par value, which is not beneficial to creditors.

In the process of raising, more funds can be raised with the same number of shares than calculated at par, so that the capital of the company can be increased accordingly [6]. This situation is usually called premium shares.

\section{Analysis of Influencing Factors of Stock Issuance Pricing}

\subsection{Ontological Factors Affecting Stock Issuance}

Under normal circumstances, the issue price depends on the actual operating conditions of the issuer. Noumenon factors and environmental factors are particularly important [7]. Noumenon factors include profit level, capital status, future profit, quality of employees, cost control, enterprise management level and other factors. At the same time, the popularity of corporate brands and the social evaluation of issuers themselves are also important factors that determine the stock issue price. The brand has certain popularity, and the issuer has a good public image, which will increase the number of market demand and produce a strong response, thus the issue price will be improved to a certain extent.

When new shares are issued, the information of issuers is asymmetric. This situation mainly refers to the asymmetry of the actual ability of the operators of related companies and the asymmetry of information about the quality of products or projects of enterprises. Under normal circumstances, it mainly refers to the strict management and supervision of the projects invested by enterprises and whether they work hard. In economic development, the first type of information asymmetry will lead to adverse selection, and the second type of information asymmetry has moral hazards.

In the daily operation of enterprises, production, operation and management are particularly important, and the strict degree of enterprise management will have a direct impact on the economic benefits and efficiency of enterprises. Management ability is mainly reflected in the three aspects of production, supply and sales, which constitute a complete management system. So that it can be more convenient to manage and control the ability.

\subsection{Environmental Factors Affecting Stock Issuance}

Environmental factors have an impact on the stock issue price of enterprises through environmental impact. The key of environmental factors lies in the factors that have obvious influence on the internal production value and internal characteristics of the enterprise, thus the factors that have a certain influence on the stock price, and the external factors that have nothing to do with the characteristics of the enterprise are not considered.

External environmental factors mainly include the current macroeconomic 
situation, Shanghai Composite Index, GDP, financial structure and so on [8]. Today's overall economic policies can affect the supply and demand of funds in the stock market, and have a direct impact on the pricing of new shares. Economic cycle and macro-economy will have a psychological impact on investors' investment behavior, thus investors have a greater impact on stock prices. When facing these environmental factors, the fluctuation of stock price is particularly obvious. For example, fiscal policy expands the profit rate of enterprises, which can promote the development of economic market and make the stock price rise to a certain extent; the increase of profit rate in financial market will cause the decline of stock value.

The influencing factors of the stock market are a long-term investigation process. Although environmental factors have little influence on value creation, the important role of environmental factors is to analyze the characteristics of enterprises, so as to show the influence of environmental factors on IPO pricing.

\section{The Research on China's Stock Issuance}

\subsection{Selection of Stock Samples}

In the primary market, issuers will sell securities to the public for the first time. Usually refers to the initial issuance of new securities by unlisted companies to the public. Stock exchanges provide a link between savings in the household sector and economic investment in enterprises. It mobilizes savings and puts them as securities into these enterprises, which are favored by investors for their future growth prospects, good returns and capital appreciation. Most transactions are conducted in the secondary market. The market in which new securities are issued to the public for the first time or traded after listing in the primary market is called the secondary market. Stock market and bond market are also included. The decision to go public, or to construct an initial public offering (IPO), represents an important milestone in a company's life cycle. Companies go public for several reasons. At first, enterprises can reduce the consumption of costs when raising funds. By switching to the stock market, entrepreneurs and existing shareholders have the opportunity to diversify their investments by converting them into cash.

After nearly 30 years' development, China's securities market is developing steadily and gradually forming a scale [9]. From the aspects of financing quota, investment quantity and investor quantity of listed companies, China's capital market has reached a certain scale, and the securities market is playing an increasingly important role in China's economic development. Therefore, the new shares issued from 2014 to 2018 are selected as the research object.

\subsection{Principal Component Analysis}

At present, principal component analysis (principal component analysis) can effectively reduce the dimension of data, which simplifies multiple related indica- 
tors into a few comprehensive indicators [10]. Users can compress the information of multiple variables into several comprehensive variables and extract effective principal components.

The principal component extracted in principal component analysis is a linear combination of original variables, and its model can be expressed by the following formula:

$$
\left\{\begin{array}{l}
Y_{1}=a_{11} x_{1}+a_{12} x_{2}+\cdots+a_{1 n} x_{n} \\
Y_{2}=a_{21} x_{1}+a_{22} x_{2}+\cdots+a_{2 n} x_{n} \\
\cdots \\
Y_{n}=a_{n 1} x_{1}+a_{n 2} x_{2}+\cdots+a_{n n} x_{n}
\end{array}\right.
$$

Among them, data $X$ is the matrix data of the principal component to be proposed, and a data $X$ has $n$ variables, which are $x_{1}, x_{2}, \cdots, x_{n}$; through the $X$ principal components can be extracted from linear changes of data $Y_{1}, Y_{2}, \cdots, Y_{n}$ There is no correlation between the principal components; principal component $Y_{1}, Y_{2}, \cdots, Y_{n}$. For data $X$ and the coefficients are satisfied with the linear combination of variables in $i_{i 1}^{2}+a_{i 2}^{2}+\cdots+a_{i n}^{2}=1, i=1,2, \cdots, n$; for each famous stock, it is its and data respectively $X$. The combination with the largest variance in linear combination, that is, principal component $Y_{1}$ is a variable $x_{1}, x_{2}, \cdots, x_{n}$ The principal component with the largest variance in all linear combinations $Y_{2}$. For and principal component $Y_{1}$ least relevant and variable $x_{1}, x_{2}, \cdots, x_{n}$. All linear equations have the smallest combined variance, and so on.

In this paper, 100 listed companies with stable policies from 2014 to 2018 are selected by random sampling (Tables 2-6).

Because there are many influencing factors, but the number of samples is relatively small, principal component analysis will be used to comprehensively evaluate various factors, so as to extract principal components. The factors that affect the IPO pricing can be divided into two relatively important factors: the main factor and the environmental factor. Compared with the main factors, I think there are many kinds of environmental factors, and the degree of their influence is also different. In addition, the data of the related factors that affect the main factors are not clear, so it is impossible to carry out good data analysis. And the most important environmental factors have a relatively obvious influence on stock prices. External environmental factors mainly include financial and current economic situation, GDP and so on. Considering the diversity and complexity of environmental factors, we can not carry out one-to-one analysis and research on the impact of various environmental factors, and can not form a unified. Usually, the impact of gold on the economy can not be ignored. As an alternative tool of assets, gold is a very important aspect of economic analysis. Therefore, this paper will select five influencing factors which have an important influence on stock value, such as RMB exchange rate, stock turnover, gold price, Shanghai Composite Index and per capita GDP, and analyze them (Tables 7-14). 
Table 2. Summary of sampled stocks of listed companies in 2014.

\begin{tabular}{|c|c|c|c|c|c|c|c|}
\hline Code & Name & $\begin{array}{l}\text { Date of the } \\
\text { prospectus }\end{array}$ & Listing board & Issue pricee & $\begin{array}{l}\text { Price-earnings } \\
\text { ratio }\end{array}$ & $\begin{array}{l}\text { opening } \\
\text { quotation }\end{array}$ & $\begin{array}{l}\text { The First-day } \\
\text { Closing Price }\end{array}$ \\
\hline 300397 & Tianhe defense & $2014 / 08 / 20$ & GEM & $24.05 ¥$ & 20.73 & $28.86 ¥$ & $34.63 ¥$ \\
\hline 300396 & Dirui medical & $2014 / 08 / 20$ & GEM & $29.54 ¥$ & 20.80 & $35.45 ¥$ & $42.54 ¥$ \\
\hline 300390 & $\begin{array}{l}\text { Tianhua super } \\
\text { clean }\end{array}$ & $2014 / 07 / 15$ & GEM & $8.47 ¥$ & 18.29 & $10.16 ¥$ & $18.29 ¥$ \\
\hline 603168 & Sapais & $2014 / 06 / 11$ & Main-Board & $21.85 ¥$ & 14.05 & $26.22 ¥$ & $31.46 ¥$ \\
\hline 002730 & $\begin{array}{l}\text { Electro optic } \\
\text { technology }\end{array}$ & $2014 / 09 / 16$ & SME & $8.07 ¥$ & 19.59 & $9.68 ¥$ & $11.62 ¥$ \\
\hline 603169 & $\begin{array}{l}\text { Orchid stone } \\
\text { reloading }\end{array}$ & $2014 / 09 / 16$ & Main-Board & $1.68 ¥$ & 21.73 & $2.02 ¥$ & $2.42 ¥$ \\
\hline 002731 & Cuihua jewelry & $2014 / 10 / 24$ & SME & $11.92 ¥$ & 17.28 & $15.73 ¥$ & $17.16 ¥$ \\
\hline 603456 & Kyushu medicine & $2014 / 09 / 16$ & Main-Board & $15.43 ¥$ & 22.36 & $18.52 ¥$ & $22.22 ¥$ \\
\hline 300392 & Teng letter shares & $2014 / 08 / 20$ & GEM & $26.10 ¥$ & 22.70 & $31.32 ¥$ & $37.58 ¥$ \\
\hline 002729 & Haolilai & $2014 / 08 / 20$ & SME & $11.90 ¥$ & 19.29 & $14.28 ¥$ & $17.14 ¥$ \\
\hline 300395 & Philippe & $2014 / 08 / 20$ & GEM & $19.13 ¥$ & 18.94 & $25.26 ¥$ & $27.55 ¥$ \\
\hline 603306 & $\begin{array}{l}\text { Chinachem } \\
\text { Technology }\end{array}$ & $2014 / 08 / 20$ & Main-Board & $12.08 ¥$ & 19.24 & $14.50 ¥$ & $17.40 ¥$ \\
\hline 603166 & Fuda shares & $2014 / 11 / 17$ & Main-Board & $5.80 ¥$ & 20.00 & $8.35 ¥$ & $8.35 ¥$ \\
\hline 601579 & Huiji Mountain & $2014 / 07 / 15$ & Main-Board & $4.43 ¥$ & 14.42 & $5.32 ¥$ & $6.38 ¥$ \\
\hline 603126 & $\begin{array}{l}\text { Sinoma energy } \\
\text { saving }\end{array}$ & $2014 / 07 / 15$ & Main-Board & $3.46 ¥$ & 21.63 & $4.15 ¥$ & $4.98 ¥$ \\
\hline 603288 & $\begin{array}{c}\text { Haitian taste } \\
\text { industry }\end{array}$ & $2014 / 01 / 15$ & Main-Board & $51.25 ¥$ & 31.90 & $61.50 ¥$ & $66.41 ¥$ \\
\hline 300383 & Halo New Net & $2014 / 01 / 10$ & GEM & $38.30 ¥$ & 37.79 & $45.96 ¥$ & $55.16 ¥$ \\
\hline 300380 & $\begin{array}{c}\text { An Shuo } \\
\text { information }\end{array}$ & $2014 / 01 / 09$ & GEM & $23.40 ¥$ & 40.06 & $28.08 ¥$ & $33.70 ¥$ \\
\hline 300406 & $\begin{array}{l}\text { Nine strong } \\
\text { organisms }\end{array}$ & $2014 / 10 / 16$ & GEM & $14.32 ¥$ & 10.07 & $18.34 ¥$ & $20.62 ¥$ \\
\hline 300400 & Jintuo shares & $2014 / 09 / 16$ & GEM & $7.60 ¥$ & 21.11 & $9.84 ¥$ & $10.94 ¥$ \\
\hline
\end{tabular}

Table 3. Summary of sampled stocks of listed companies in 2015.

\begin{tabular}{|c|c|c|c|c|c|c|c|}
\hline Code & Name & $\begin{array}{l}\text { Date of the } \\
\text { prospectus }\end{array}$ & Listing board & Issue price & $\begin{array}{l}\text { Price-earnings } \\
\text { ratio }\end{array}$ & $\begin{array}{l}\text { opening } \\
\text { quotation }\end{array}$ & $\begin{array}{l}\text { The First-day } \\
\text { Closing Price }\end{array}$ \\
\hline 300480 & $\begin{array}{l}\text { Optics and power } \\
\text { technology }\end{array}$ & $2015 / 06 / 23$ & GEM & $7.28 ¥$ & 22.99 & $9.49 ¥$ & $10.48 ¥$ \\
\hline 300481 & Puyang Huicheng & $2015 / 06 / 19$ & GEM & $9.13 ¥$ & 22.95 & $12.06 ¥$ & $13.15 ¥$ \\
\hline 300482 & Wanfu biology & $2015 / 06 / 19$ & GEM & $16.00 ¥$ & 18.56 & $20.94 ¥$ & $23.04 ¥$ \\
\hline 300490 & Huazi technology & $2015 / 12 / 23$ & GEM & $9.90 ¥$ & 22.98 & $12.00 ¥$ & $13.09 ¥$ \\
\hline 300491 & Tonghe technology & $2015 / 12 / 23$ & GEM & $10.48 ¥$ & 22.98 & $13.84 ¥$ & $15.09 ¥$ \\
\hline 300492 & $\begin{array}{c}\text { Mountain tripod } \\
\text { design }\end{array}$ & $2015 / 12 / 14$ & GEM & $6.90 ¥$ & 22.96 & $8.28 ¥$ & $9.94 ¥$ \\
\hline
\end{tabular}




\begin{tabular}{|c|c|c|c|c|c|c|c|}
\hline & & & & & & & \\
\hline 300496 & $\begin{array}{l}\text { Zhongke } \\
\text { Chuangda }\end{array}$ & $2015 / 12 / 02$ & GEM & $23.27 ¥$ & 22.99 & $28.41 ¥$ & $33.51 ¥$ \\
\hline 300497 & Fuxiang shares & $2015 / 12 / 11$ & GEM & $15.33 ¥$ & 21.79 & $18.96 ¥$ & $22.08 ¥$ \\
\hline 002771 & $\begin{array}{c}\text { True visual } \\
\text { communication }\end{array}$ & $2015 / 06 / 18$ & SME & $12.78 ¥$ & 22.98 & $16.61 ¥$ & $18.40 ¥$ \\
\hline 002772 & $\begin{array}{c}\text { Zhongxing } \\
\text { mushroom } \\
\text { industry }\end{array}$ & $2015 / 06 / 17$ & SME & $13.00 ¥$ & 22.98 & $15.60 ¥$ & $18.72 ¥$ \\
\hline 002773 & $\begin{array}{c}\text { Kanghong } \\
\text { pharmaceutical } \\
\text { industry }\end{array}$ & $2015 / 06 / 17$ & SME & $13.62 ¥$ & 22.98 & $16.34 ¥$ & $19.61 ¥$ \\
\hline 002770 & $\begin{array}{l}\text { Cody dairy } \\
\text { industry }\end{array}$ & $2015 / 06 / 19$ & SME & $6.85 ¥$ & 20.81 & $8.22 ¥$ & $9.86 ¥$ \\
\hline 002769 & Prutone & $2015 / 06 / 18$ & SME & $28.49 ¥$ & 19.64 & $37.61 ¥$ & $41.03 ¥$ \\
\hline 002768 & Guoen shares & $2015 / 06 / 18$ & SME & $17.47 ¥$ & 22.99 & $22.86 ¥$ & $25.16 ¥$ \\
\hline 002767 & Pioneer Electronics & $2015 / 06 / 03$ & SME & $14.87 ¥$ & 22.43 & $17.84 ¥$ & $21.41 ¥$ \\
\hline 002766 & Suoling shares & $2015 / 06 / 03$ & SME & $7.53 ¥$ & 22.82 & $9.94 ¥$ & $10.84 ¥$ \\
\hline 603223 & Hengtong shares & $2015 / 06 / 19$ & Main-Board & $8.31 ¥$ & 22.97 & $11.97 ¥$ & $11.97 ¥$ \\
\hline 603227 & $\begin{array}{l}\text { Xuefeng } \\
\text { technology }\end{array}$ & $2015 / 05 / 06$ & Main-Board & $4.98 ¥$ & 22.95 & $7.17 ¥$ & $7.17 ¥$ \\
\hline 603268 & Songfa shares & $2015 / 03 / 11$ & Main-Board & $11.66 ¥$ & 22.86 & $13.99 ¥$ & $16.79 ¥$ \\
\hline 603299 & Su Yanjing God & $2015 / 12 / 23$ & Main-Board & $3.69 ¥$ & 22.92 & $5.31 ¥$ & $5.31 ¥$ \\
\hline
\end{tabular}

Table 4. Summary of sampled stocks of listed companies in 2016.

\begin{tabular}{|c|c|c|c|c|c|c|c|}
\hline Code & Name & $\begin{array}{l}\text { Date of the } \\
\text { prospectus }\end{array}$ & Listing board & Issue price & $\begin{array}{l}\text { Price-earnings } \\
\text { ratio }\end{array}$ & $\begin{array}{l}\text { opening } \\
\text { quotation }\end{array}$ & $\begin{array}{l}\text { The First-day } \\
\text { Closing Price }\end{array}$ \\
\hline 300502 & Xinyisheng & $2016 / 02 / 23$ & GEM & $21.47 ¥$ & 18.58 & $25.76 ¥$ & $30.92 ¥$ \\
\hline 300503 & $\begin{array}{l}\text { Haozhi } \\
\text { electromechanical }\end{array}$ & $2016 / 02 / 29$ & GEM & $7.72 ¥$ & 22.98 & $9.26 ¥$ & $11.12 ¥$ \\
\hline 300505 & Chuan Jinnuo & $2016 / 03 / 04$ & GEM & $10.25 ¥$ & 22.98 & $12.30 ¥$ & $14.76 ¥$ \\
\hline 300507 & Suo sensing & $2016 / 04 / 20$ & GEM & $24.92 ¥$ & 22.99 & $32.89 ¥$ & $35.88 ¥$ \\
\hline 300508 & Weihong shares & $2016 / 04 / 08$ & GEM & $20.08 ¥$ & 22.98 & $26.51 ¥$ & $28.92 ¥$ \\
\hline 300510 & $\begin{array}{c}\text { Golden crown } \\
\text { shares }\end{array}$ & $2016 / 04 / 26$ & GEM & $12.30 ¥$ & 22.99 & $16.24 ¥$ & $17.71 ¥$ \\
\hline 300512 & Central Asia shares & $2016 / 05 / 17$ & GEM & $20.91 ¥$ & 22.96 & $25.09 ¥$ & $30.11 ¥$ \\
\hline 300517 & $\begin{array}{c}\text { Haibo Heavy } \\
\text { Branch }\end{array}$ & $2016 / 07 / 07$ & GEM & $10.04 ¥$ & 22.97 & $13.26 ¥$ & $14.46 ¥$ \\
\hline 002818 & Fu Sen Mei & $2016 / 10 / 25$ & SME & $23.49 ¥$ & 22.99 & $31.01 ¥$ & $33.83 ¥$ \\
\hline 002817 & $\begin{array}{l}\text { Huangshan } \\
\text { Capsule }\end{array}$ & $2016 / 10 / 13$ & SME & $13.88 ¥$ & 22.98 & $16.66 ¥$ & $19.99 ¥$ \\
\hline 002816 & And Koda & $2016 / 10 / 12$ & SME & $8.29 ¥$ & 22.98 & $10.63 ¥$ & $11.94 ¥$ \\
\hline 002815 & $\begin{array}{l}\text { Chongda } \\
\text { technology }\end{array}$ & $2016 / 09 / 22$ & SME & $16.31 ¥$ & 22.98 & $21.22 ¥$ & $23.49 ¥$ \\
\hline
\end{tabular}




\section{Continued}

\begin{tabular}{|c|c|c|c|c|c|c|c|}
\hline 002813 & $\begin{array}{l}\text { Luchang } \\
\text { technology }\end{array}$ & $2016 / 09 / 23$ & SME & $6.89 ¥$ & 22.97 & $8.95 ¥$ & $9.92 ¥$ \\
\hline 002812 & Enjie shares & $2016 / 08 / 31$ & SME & $23.41 ¥$ & 22.99 & 28.09¥ & $33.71 ¥$ \\
\hline 002811 & $\begin{array}{c}\text { Asia Pacific } \\
\text { International }\end{array}$ & $2016 / 08 / 30$ & SME & $13.99 ¥$ & 22.98 & $18.47 ¥$ & $20.15 ¥$ \\
\hline 603090 & Hongsheng shares & $2016 / 08 / 16$ & Main-Board & $8.47 ¥$ & 22.98 & $10.16 ¥$ & $12.20 ¥$ \\
\hline 603069 & Haiqi Group & $2016 / 06 / 29$ & Main-Board & $3.82 ¥$ & 18.20 & $4.58 ¥$ & $5.50 ¥$ \\
\hline 603067 & Zhenhua shares & $2016 / 09 / 01$ & Main-Board & $6.13 ¥$ & 22.98 & $8.83 ¥$ & $8.83 ¥$ \\
\hline 603060 & $\begin{array}{c}\text { National } \\
\text { Inspection Group }\end{array}$ & $2016 / 10 / 28$ & Main-Board & $10.04 ¥$ & 22.97 & $12.05 ¥$ & $14.46 ¥$ \\
\hline 603887 & City land shares & $2016 / 10 / 10$ & Main-Board & $12.13 ¥$ & 22.97 & $14.56 ¥$ & $17.47 ¥$ \\
\hline
\end{tabular}

Table 5. Summary of sampled stocks of listed companies in 2017.

\begin{tabular}{|c|c|c|c|c|c|c|c|}
\hline Code & Name & $\begin{array}{l}\text { Date of the } \\
\text { prospectus }\end{array}$ & Listing board & Issue price & $\begin{array}{c}\text { Price-earnings } \\
\text { ratio }\end{array}$ & $\begin{array}{c}\text { opening } \\
\text { quotation }\end{array}$ & $\begin{array}{l}\text { The First-day } \\
\text { Closing Price }\end{array}$ \\
\hline 300625 & Trio Aurora & $2017 / 03 / 07$ & GEM & $19.30 ¥$ & 22.99 & $23.16 ¥$ & $27.79 ¥$ \\
\hline 300626 & Huarui shares & $2017 / 03 / 09$ & GEM & $7.50 ¥$ & 22.98 & $9.00 ¥$ & $10.80 ¥$ \\
\hline 300640 & Deyi Wenchuang & $2017 / 04 / 05$ & GEM & $9.41 ¥$ & 22.98 & $11.29 ¥$ & $13.55 ¥$ \\
\hline 300643 & Wantong Zhikong & $2017 / 05 / 05$ & GEM & $4.30 ¥$ & 22.01 & $5.16 ¥$ & $6.19 ¥$ \\
\hline 300642 & Viewing life & $2017 / 04 / 12$ & GEM & $36.10 ¥$ & 22.99 & $47.65 ¥$ & $51.98 ¥$ \\
\hline 300641 & Zhengdan shares & $2017 / 04 / 06$ & GEM & $10.73 ¥$ & 22.98 & $12.88 ¥$ & $15.45 ¥$ \\
\hline 300653 & $\begin{array}{l}\text { Orthoceanic } \\
\text { organisms }\end{array}$ & $2017 / 05 / 03$ & GEM & $11.72 ¥$ & 22.98 & $15.47 ¥$ & $16.88 ¥$ \\
\hline 300654 & Century Tianhong & $2017 / 09 / 14$ & GEM & $7.71 ¥$ & 22.98 & $9.25 ¥$ & $11.10 ¥$ \\
\hline 002878 & Yuan Long Yatu & $2017 / 05 / 19$ & SME & $14.48 ¥$ & 22.75 & $17.38 ¥$ & $20.85 ¥$ \\
\hline 002879 & $\begin{array}{l}\text { Long cable } \\
\text { technology }\end{array}$ & $2017 / 06 / 01$ & SME & $18.02 ¥$ & 22.99 & $23.78 ¥$ & $25.95 ¥$ \\
\hline 002881 & Meg intelligence & $2017 / 06 / 09$ & SME & $8.96 ¥$ & 22.98 & $11.83 ¥$ & $12.90 ¥$ \\
\hline 002887 & Green ecology & $2017 / 07 / 20$ & SME & $42.01 ¥$ & 22.98 & $55.45 ¥$ & $60.49 ¥$ \\
\hline 002888 & Hivi Technology & $2017 / 07 / 12$ & SME & $8.97 ¥$ & 22.97 & $10.76 ¥$ & $12.92 ¥$ \\
\hline 002891 & $\begin{array}{l}\text { Zhongchong } \\
\text { shares }\end{array}$ & $2017 / 08 / 10$ & SME & $15.46 ¥$ & 22.98 & $18.55 ¥$ & $22.26 ¥$ \\
\hline 002893 & $\begin{array}{c}\text { Huatong thermal } \\
\text { power }\end{array}$ & 2017/09/06 & SME & $8.56 ¥$ & 22.97 & $10.27 ¥$ & $12.33 ¥$ \\
\hline 002896 & $\begin{array}{l}\text { Zhongda Dali } \\
\text { Germany }\end{array}$ & $2017 / 08 / 18$ & SME & $11.75 ¥$ & 22.99 & $15.51 ¥$ & $16.92 ¥$ \\
\hline 603938 & Sanfu shares & $2017 / 06 / 16$ & Main-Board & $9.64 ¥$ & 22.99 & $13.88 ¥$ & $13.88 ¥$ \\
\hline 603963 & $\begin{array}{c}\text { Dali } \\
\text { pharmaceutical } \\
\text { industry }\end{array}$ & 2017/09/12 & Main-Board & $12.58 ¥$ & 22.69 & $18.12 ¥$ & $18.12 ¥$ \\
\hline 603970 & $\begin{array}{c}\text { Middle peasant Li } \\
\text { Hua }\end{array}$ & $2017 / 11 / 07$ & Main-Board & $12.47 ¥$ & 22.98 & $17.96 ¥$ & $17.96 ¥$ \\
\hline 603960 & Mechatronics & $2017 / 03 / 02$ & Main-Board & $9.51 ¥$ & 22.99 & $13.69 ¥$ & $13.69 ¥$ \\
\hline
\end{tabular}


Table 6. Summary of sampled stocks of listed companies in 2018.

\begin{tabular}{|c|c|c|c|c|c|c|c|}
\hline Code & Name & $\begin{array}{l}\text { Date of the } \\
\text { prospectus }\end{array}$ & Listing board & Issue price & $\begin{array}{c}\text { Price-earnings } \\
\text { ratio }\end{array}$ & $\begin{array}{l}\text { opening } \\
\text { quotation }\end{array}$ & $\begin{array}{l}\text { The First-day } \\
\text { Closing Price }\end{array}$ \\
\hline 300741 & $\begin{array}{l}\text { Huabao } \\
\text { shares }\end{array}$ & $2018 / 02 / 13$ & GEM & $38.60 ¥$ & 22.99 & $46.32 ¥$ & $55.58 ¥$ \\
\hline 300742 & $\begin{array}{l}\text { Yue Bo } \\
\text { power }\end{array}$ & $2018 / 04 / 25$ & GEM & $23.34 ¥$ & 22.99 & $28.01 ¥$ & $33.61 ¥$ \\
\hline 300743 & $\begin{array}{l}\text { Tiandi } \\
\text { Digital }\end{array}$ & $2018 / 04 / 04$ & GEM & $14.70 ¥$ & 22.99 & $19.40 ¥$ & $21.17 ¥$ \\
\hline 300745 & $\begin{array}{c}\text { Xinrui } \\
\text { technology }\end{array}$ & $2018 / 05 / 14$ & GEM & $11.65 ¥$ & 17.29 & $15.38 ¥$ & $16.78 ¥$ \\
\hline 300746 & $\begin{array}{l}\text { Hanjia } \\
\text { design }\end{array}$ & $2018 / 05 / 16$ & GEM & $5.62 ¥$ & 21.45 & $6.74 ¥$ & $8.09 ¥$ \\
\hline 300747 & $\begin{array}{l}\text { Rico } \\
\text { laser }\end{array}$ & $2018 / 06 / 13$ & GEM & $38.11 ¥$ & 17.96 & $45.73 ¥$ & $54.88 ¥$ \\
\hline 300748 & $\begin{array}{l}\text { Gold force } \\
\text { permanent } \\
\text { magnet }\end{array}$ & $2018 / 09 / 06$ & GEM & $5.39 ¥$ & 22.98 & $6.47 ¥$ & $7.76 ¥$ \\
\hline 300749 & $\begin{array}{l}\text { Dinggu } \\
\text { Jichuang }\end{array}$ & $2018 / 09 / 13$ & GEM & $12.22 ¥$ & 22.99 & $14.66 ¥$ & $17.60 ¥$ \\
\hline 002925 & $\begin{array}{l}\text { Yingqu } \\
\text { technology }\end{array}$ & $2018 / 01 / 04$ & SME & $22.50 ¥$ & 22.99 & $27.00 ¥$ & $32.40 ¥$ \\
\hline 002927 & $\begin{array}{c}\text { Tai Yong Long } \\
\text { March }\end{array}$ & $2018 / 02 / 07$ & SME & $14.78 ¥$ & 22.99 & $17.74 ¥$ & $21.28 ¥$ \\
\hline 002930 & $\begin{array}{l}\text { Hirokawa } \\
\text { Wisdom }\end{array}$ & $2018 / 03 / 14$ & SME & $8.53 ¥$ & 22.97 & $10.24 ¥$ & $12.28 ¥$ \\
\hline 002932 & $\begin{array}{l}\text { Mingde } \\
\text { biology }\end{array}$ & $2018 / 06 / 29$ & SME & $20.45 ¥$ & 22.99 & $24.54 ¥$ & $29.45 ¥$ \\
\hline 002933 & $\begin{array}{l}\text { Emerging } \\
\text { equipment }\end{array}$ & $2018 / 08 / 15$ & SME & $22.45 ¥$ & 22.99 & $26.94 ¥$ & $32.33 ¥$ \\
\hline 002937 & $\begin{array}{c}\text { Xingrui } \\
\text { technology }\end{array}$ & 2018.09/12 & SME & $9.94 ¥$ & 22.99 & $11.93 ¥$ & $14.31 ¥$ \\
\hline 002938 & $\begin{array}{l}\text { Pengding } \\
\text { Holdings }\end{array}$ & $2018 / 09 / 05$ & SME & $16.07 ¥$ & 22.99 & $19.28 ¥$ & $23.14 ¥$ \\
\hline 002939 & $\begin{array}{l}\text { Great Wall } \\
\text { Securities }\end{array}$ & $2018 / 10 / 17$ & SME & $6.31 ¥$ & 22.98 & $7.75 ¥$ & $9.09 ¥$ \\
\hline 603156 & $\begin{array}{l}\text { Yangyuan } \\
\text { drink }\end{array}$ & $2018 / 01 / 31$ & Main-Board & $78.73 ¥$ & 17.74 & $94.48 ¥$ & $113.37 ¥$ \\
\hline 603214 & $\begin{array}{l}\text { Baby-friendly } \\
\text { room }\end{array}$ & $2018 / 03 / 21$ & Main-Board & $19.95 ¥$ & 22.98 & $23.94 ¥$ & $28.73 ¥$ \\
\hline 603895 & $\begin{array}{l}\text { Tianyong } \\
\text { intelligence }\end{array}$ & $2018 / 01 / 10$ & Main-Board & $18.22 ¥$ & 22.99 & $22.00 ¥$ & $26.40 ¥$ \\
\hline 603871 & $\begin{array}{c}\text { Jiayou } \\
\text { International }\end{array}$ & $2018 / 01 / 25$ & Main-Board & $41.80 ¥$ & 22.99 & $50.27 ¥$ & $60.32 ¥$ \\
\hline
\end{tabular}

*The data comes from tonghuashun of northeast securities. 
Table 7. Environmental factor data.

\begin{tabular}{|c|c|c|c|c|c|}
\hline Year & $\begin{array}{c}\text { RMB exchange rate } \\
\text { (annual average } \\
\text { price) }\end{array}$ & $\begin{array}{c}\text { Transaction amount } \\
\text { of stock ( } 100 \text { million } \\
\text { yuan })\end{array}$ & Gold price (USD) & $\begin{array}{l}\text { Shanghai Composite } \\
\text { Index (closing price) }\end{array}$ & Per capita GDP \\
\hline 2000 & 827.84 & 60827 & 279.01 & 2073.48 & 7857.68 \\
\hline 2001 & 827.7 & 38305 & 271.08 & 1645.97 & 8621.71 \\
\hline 2002 & 827.7 & 27990 & 309.88 & 1357.86 & 9398.05 \\
\hline 2003 & 827.7 & 32115 & 363.57 & 1497.04 & 10541.97 \\
\hline 2004 & 827.68 & 42334 & 409.72 & 1266.5 & 12335.58 \\
\hline 2005 & 819.17 & 31665 & 444.74 & 1161.06 & 14185.36 \\
\hline 2006 & 797.18 & 90469 & 603.46 & 2675.47 & 16499.7 \\
\hline 2007 & 760.4 & 460556 & 695.39 & 5261.56 & 20169.46 \\
\hline 2008 & 694.51 & 267113 & 871.57 & 1820.81 & 23707.71 \\
\hline 2009 & 683.1 & 533161 & 963.35 & 3277.14 & 25575.48 \\
\hline 2010 & 676.95 & 545634 & 1232.57 & 2808.08 & 30494.44 \\
\hline 2011 & 645.88 & 421650 & 1567.95 & 2199.417 & 35931.53 \\
\hline 2012 & 631.25 & 314667 & 1677.75 & 2269.128 & 39446.62 \\
\hline 2013 & 619.32 & 468072 & 1409.08 & 2115.98 & 43213.8 \\
\hline 2014 & 614.28 & 742385 & 1266.4 & 3234.68 & 46490.78 \\
\hline 2015 & 622.84 & 2368150 & 1148.19 & 3539.18 & 51571.71 \\
\hline 2016 & 664.23 & 1273845 & 1252.3 & 2988.6 & 53974.23 \\
\hline 2017 & 650 & 1124625 & 1332.3 & 3139.88 & 59201.72 \\
\hline 2018 & 619.32 & 901739 & 1365.45 & 3189.96 & 98274.85 \\
\hline
\end{tabular}

Principal component analysis using SPSS.

FACTOR

/VARIABLES RMB exchange rate (annual average price) stock turnover (100 million $¥$ ) gold price (USD) Shanghai Composite Index (closing price) per capita GDP

\section{/MISSING LISTWISE}

/ANALYSIS RMB exchange rate (annual average price) stock turnover (100 million $¥$ ) gold price (USD) Shanghai Composite Index (closing price) per capita GDP

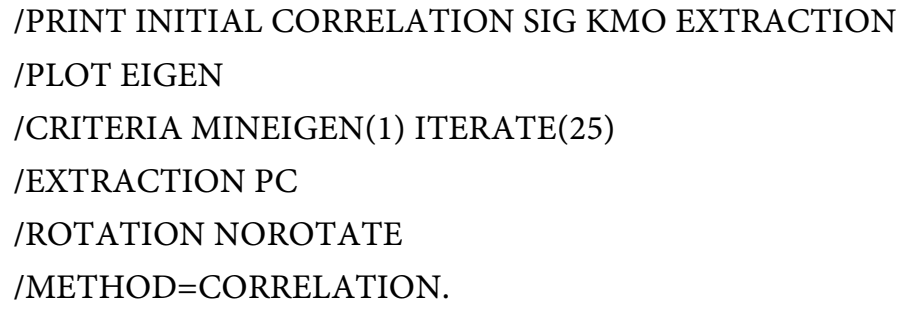


Table 8. Notes.

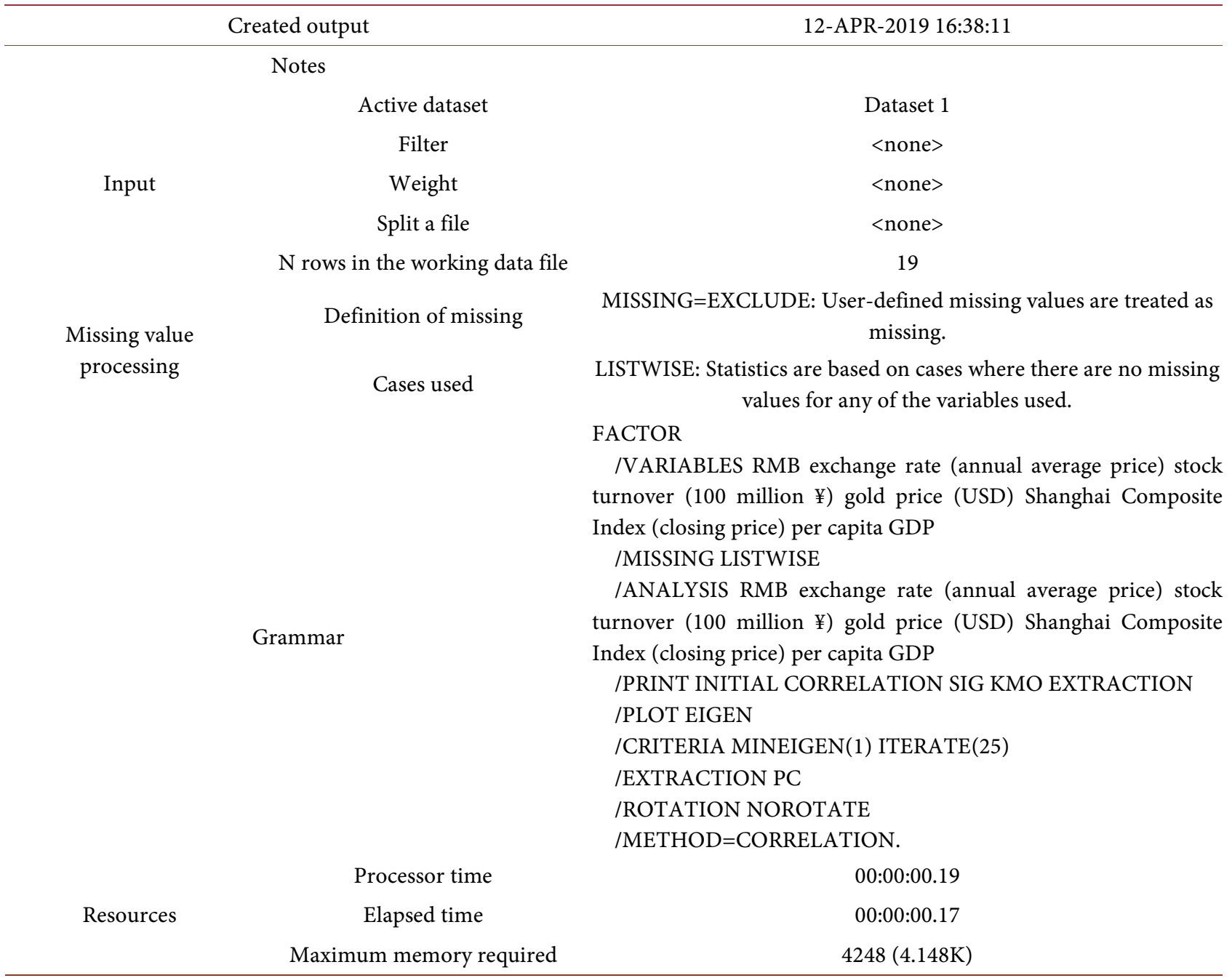

[Dataset 1].

Table 9. Correlation Matrix (1).

\begin{tabular}{|c|c|c|c|c|}
\hline & & $\begin{array}{l}\text { RMB exchange } \\
\text { rate (annual } \\
\text { average price) }\end{array}$ & $\begin{array}{c}\text { Transaction } \\
\text { amount of stock } \\
\text { (100 million } ¥)\end{array}$ & Gold price (USD) \\
\hline \multirow{5}{*}{ Correlation } & RMB exchange rate (annual average price) & 1.000 & -0.673 & -0.954 \\
\hline & Transaction amount of stock (100 million $¥)$ & -0.673 & 1.000 & 0.541 \\
\hline & Gold price (USD) & -0.954 & 0.541 & 1.000 \\
\hline & Shanghai Composite Index (closing price) & -0.480 & 0.565 & 0.401 \\
\hline & Per capita GDP & -0.816 & 0.677 & 0.765 \\
\hline \multirow{5}{*}{ Sig. (Unilateral) } & RMB exchange rate (annual average price) & & 0.001 & 0.000 \\
\hline & Transaction amount of stock (100 million $¥)$ & 0.001 & & 0.008 \\
\hline & Gold price (USD) & 0.000 & 0.008 & \\
\hline & Shanghai Composite Index (closing price) & 0.019 & 0.006 & 0.044 \\
\hline & Per capita GDP & 0.000 & 0.001 & 0.000 \\
\hline
\end{tabular}


Table 10. Correlation Matrix (2).

\begin{tabular}{|c|c|c|c|}
\hline & & $\begin{array}{c}\text { Shanghai } \\
\text { Composite Index } \\
\text { (closing price) }\end{array}$ & $\begin{array}{l}\text { Per capita } \\
\text { GDP }\end{array}$ \\
\hline \multirow{5}{*}{ Correlation } & $\begin{array}{l}\text { RMB exchange rate } \\
\text { (annual average price) }\end{array}$ & -0.480 & -0.816 \\
\hline & $\begin{array}{l}\text { Transaction amount of stock } \\
\qquad(100 \text { million } ¥)\end{array}$ & 0.565 & 0.677 \\
\hline & Gold price (USD) & 0.401 & 0.765 \\
\hline & $\begin{array}{l}\text { Shanghai Composite Index } \\
\text { (closing price) }\end{array}$ & 1.000 & 0.445 \\
\hline & Per capita GDP & 0.445 & 1.000 \\
\hline \multirow{5}{*}{$\begin{array}{c}\text { Sig. } \\
\text { (Unilateral) }\end{array}$} & $\begin{array}{l}\text { RMB exchange rate } \\
\text { (annual average price) }\end{array}$ & 0.019 & 0.000 \\
\hline & $\begin{array}{l}\text { Transaction amount of stock } \\
\qquad(100 \text { million } ¥)\end{array}$ & 0.006 & 0.001 \\
\hline & Gold price (USD) & 0.044 & 0.000 \\
\hline & $\begin{array}{l}\text { Shanghai Composite Index } \\
\text { (closing price) }\end{array}$ & & 0.028 \\
\hline & Per capita GDP & 0.028 & \\
\hline
\end{tabular}

Table 11. KMO and Bartlett inspection.

\begin{tabular}{lcc}
\hline Kaiser-Meyer-Olkin metric of sampling adequacy. & 0.747 \\
\hline & Approximate chi-square & 75.236 \\
Bartlett's sphericity test & df & 10 \\
& Sig. & 0.000 \\
\hline
\end{tabular}

Table 12. Common factor variance

\begin{tabular}{ccc}
\hline & Initial & Extraction \\
\hline RMB exchange rate (annual average price) & 1.000 & 0.899 \\
Transaction amount of stock (100 million $¥)$ & 1.000 & 0.661 \\
Gold price (USD) & 1.000 & 0.792 \\
Shanghai Composite Index (closing price) & 1.000 & 0.422 \\
Per capita GDP & 1.000 & 0.797 \\
\hline
\end{tabular}

Extraction method: Principal component analysis.

Table 13. Total variance explained.

\begin{tabular}{ccccccc}
\hline & \multicolumn{3}{c}{ Initial eigenvalue } & \multicolumn{2}{c}{ Extract sum of squares and load } \\
\cline { 2 - 6 } Composition & Total & $\begin{array}{c}\text { \% of } \\
\text { variance }\end{array}$ & Cumulative \% & Total & $\begin{array}{c}\text { \% of } \\
\text { variance }\end{array}$ & Cumulative \% \\
\hline 1 & 3.570 & 71.410 & 71.410 & 3.570 & 71.410 & 71.410 \\
2 & 0.761 & 15.226 & 86.636 & & & \\
3 & 0.410 & 8.202 & 94.838 & & & \\
4 & 0.227 & 4.546 & 99.385 & & & \\
5 & 0.031 & 0.615 & 100.000 & & & \\
\hline
\end{tabular}

Extraction method: Principal component analysis. 
Table 14. Component Matrix A.

\begin{tabular}{cc}
\hline & Composition \\
\cline { 2 - 2 } & 1 \\
\hline RMB exchange rate (annual average price) & -0.948 \\
Transaction amount of stock (100 million $¥)$ & 0.813 \\
Gold price (USD) & 0.890 \\
Shanghai Composite Index (closing price) & 0.649 \\
Per capita GDP & 0.893 \\
\hline
\end{tabular}

Extraction method: Principal components. A, 1 component has been extracted.

\section{Conclusions}

Through the understanding of stock pricing theory, this paper analyzes the factors that affect the pricing of stock issuance. Environmental factors can not only significantly affect the fluctuation of stock prices, but also have a wide variety of environmental factors, which have complex forms of influence on stock prices and different degrees of influence on stock prices. Therefore, this paper will select five influencing factors which have an important influence on stock value, such as RMB exchange rate, stock turnover, gold price, Shanghai Composite Index and per capita GDP, and analyze them. Our country's securities market is constantly developing, and stock pricing has become our concern for more and more months.

At the beginning of studying the current price of IPO theory, Combined with the characteristics of China's stock listing subjects, from the data from 2000 to 2018, this paper analyzes the factors affecting the pricing of new shares from five aspects: $\mathrm{RMB}$ exchange rate, stock turnover, gold price, Shanghai Composite Index and per capita GDP, and finds that the application effect of the model is better, which shows that the applicability of the model is better. At the same time, from the results of the model, we can see that the RMB exchange rate has a great influence on the stock issue price, and the stock transaction amount, gold price, Shanghai Composite Index and per capita GDP also have a certain influence on the stock issue price. In addition, the capital market should also strengthen the rational guidance of people's development based on the needs of the country, which will help upgrade China's industrial mechanism and guide the flow of quality resources to high-quality enterprises and industries.

\section{Conflicts of Interest}

The authors declare no conflicts of interest.

\section{References}

[1] Fama, E.F. and French, K.R. (1996) Multifactor Explanation of Asset Pricing Anomalies. Journal of Finance, 51, 55-84.

https://doi.org/10.1111/j.1540-6261.1996.tb05202.x 
[2] Thomsen, S. and Pedersen. T. (2000) Ownership Structure and Economic Performance in the Largest European Companies. Strategic Management Journal, 21, 689-705.

[3] Kevin, R. (1986) Why New Issues Are under Priced. Journal of Financial Economics, 15, 187-212. https://doi.org/10.1016/0304-405X(86)90054-1

[4] Zhu, L.J. (2010) Research on IPO Pricing of Chinese Listed Companies. Master's Thesis, East China Normal University, Shanghai.

[5] Hou, S.H. (1994) Analysis of Economic Factors Affecting Stock Price. Journal of Central China Normal University (Philosophy and Social Science Edition), 5-11.

[6] Tao, Y. (2003) Analysis of Factors Affecting IPO Pricing. Journal of Hunan University, 24-36.

[7] Zhang, B.G. (2002) Comparison of IPO Methods in Different Countries. Financial Research, 52-55.

[8] Li, S.D. (2005) Research on the Pricing of China's Stock Issuance. Master's Thesis, Xiangtan University, Xiangtan.

[9] Xu, P. (2013) Research on the application of multi-factor model in IPO pricing of GEM in China. Master's Thesis, Shenyang Ligong University, Shenyang.

[10] Li, H.S. (2009) Value Factors, Environmental Factors and Stock Market Pricing. Empirical Evidence Based on Chinese Listed Companies. Doctoral Dissertation, Jinan University, Guangzhou. 